\title{
A Model to Evaluate Energy Efficiency of Buildings Located in Hot and Humid Tropical Climates
}

\author{
Hernando Gómez ${ }^{1}$, Lesmes Corredor ${ }^{1}$, Karen Klever ${ }^{1}$ and Maira Sierra ${ }^{1}$ \\ ${ }^{1}$ Department of Mechanical Engineering \\ Universidad del Norte \\ Km 5 Vía Puerto Colombia, Barranquilla (Colombia) \\ Phone number:+57 5 3509509, e-mail: hgomez@uninorte.edu.co, hejgomez@yahoo.com, lcorredo@uninorte.edu.co, \\ kleverk@uninorte.edu.co, amaira@uninorte.edu.co
}

\begin{abstract}
.
An exhaustive research literature review shows that in hot and humid tropical climates the air conditioning equipment demand around 50\% of commercial building energy consumption. These weather conditions added to the corrosive environment and the lack of local availability of green materials in these developing countries don't make feasible the use of methodologies like LEED in the design and construction of buildings because high costs associated with its implementation. For these reasons a thermoeconomic model was developed to assess the construction and operating phases taking into account factors like: Colombian Caribbean Coast Region weather, conventional and high performance materials and equipment and their costs. A parametric study was carried out changing a set of building parameters like aspect ratio, orientation, glass/wall ratio, materials performance and cooling equipment types. In this way, a vapor compression cycle was taking into account to supply the chilled air and part load performance factor was taken into account to estimate annual energy consumption; to calculate cooling load the CLTD/CLF method was used keeping constant plug load index and occupation factor index. This method will help in the early design stage to assess the sustainability during the building design process.
\end{abstract}

\section{Key words}

Thermoeconomics, sustainability, buildings, tropical climates.

\section{Introduction}

The building sector is an intensive energy consumer. Statistical facts show that it consumes almost $40 \%$ of the world produced electricity to operate building service systems like HVAC systems, illumination, domestic appliances and office equipment. i.e. in tropical environments such as Southeast Asia, where temperature and humidity are high, about $50 \%$ of energy to operate the building is consumed by air conditioning (Saidur, 2009) and areas with higher temperatures as Saudi Arabia have shown similar behavior (Al-Rabghi \& Hittle, 2001).
Another important factor is the energy required to extract and produce the materials used in the structure, façade and finish of buildings. Research in LCA to evaluate the life cycle phases of the buildings have found that the construction and operation phases account in a range between $90-96 \%$ of the energy use during its LC. (Cole \& Kernan, 1996); (Kofoworola \& Gheewala, 2009) in which the former can contribute until $46 \%$ in low energy building (Sartori \& Hestnes, 2007).

In short, the energy consumption of this sector is determined by the size of the population, the area per person needed to live and the energy intensity of the building in $\mathrm{kW}-\mathrm{h} / \mathrm{m} 2$-year as is shown in Fig. 1. Can be found in the literature that an increase in urban population by $1 \%$ causes a rise in energy consumption of $2.2 \%$ (Santamouris, Papanikolau, Livada, Koronakis, \& Georgakis, 2001), thus to deal with the lack of availability of resources and to reduce the adverse impacts on the environment, the global trend is in search of significant reduction of energy intensities during its life cycle phases.

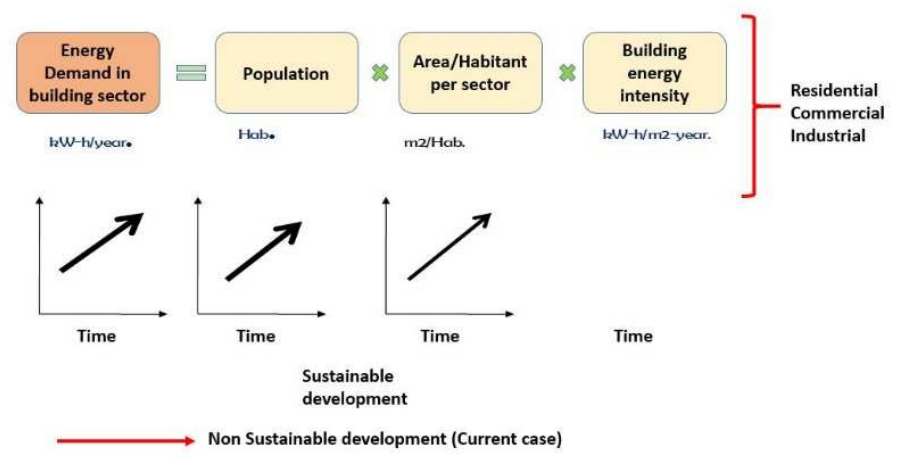

Fig. 1 Building sector Energy consumption and variables relationship.

European and American countries have been given the task of reducing energy intensity rates by introducing materials with highly recycling contents, better thermal performances, life time and use of renewable energies like sun and wind returning to bioclimatic architecture practice 
in the building design. These strategies have been allowed to pass to consume approximately $800-520 \mathrm{kWh} / \mathrm{m} 2$-year (Kibert, 2008) to almost $120-150 \mathrm{kWh} / \mathrm{m}^{2}$-year measured in terms of primary energy (Passive House Institute) depending on the energy source distribution and the adopted design strategy.

In order to attain these indicators design trends in the construction of buildings such as the high tech and low tech architecture, ecological humanism and ecological minimalism currents have appeared and reappear in recent years after the summit of Rio (Gauzing-Muller, 2001) others news such as Green buildings (GB) and the zero consumption buildings (ZEB) movement have contributed to meet these new standards.

There are also methodologies that help to assess the sustainable performance of building like: LEED in North America, BREEAM in UK and CASBEE in Japan. Also is possible to find design guidance in countries like France, Germany, Finland, Netherlands and others. These are oriented to reduce the use of energy for illumination, air conditioning, water use and heating, better integration with the environment, land use, and other relevant aspect to achieve sustainability, but not all include analysis of life cycle cost (LCC) ( (Haapio \& Viitaniemi, 2008)

As is shown, every system design deals with physical and economic constraints. In order to joint both environments, thermoecomic methods were developed by Gaggioli in 1961 and Tribus in 1962 (Gong \& Wall, 1997) combining life cycle costing with exergy analysis. The latter have an important application in resource accounting because is exergy not the energy that is consumed, destroyed and wasted and is the unique thermodynamic term that define the quality and quantity of any energy form (i.e. heat, work, flow, chemical, etc.).

Although exergy analysis and Exergetic life cycle analysis/assessment (ELCA) have been carried out in several industrial processes like heat and power generation plants, production processes and individual components (Cornelissen, 1997), recently the former has been applied in the context of building design and performance evaluation. The ECBCS Annex 49 working group of the IEA "is based on an integral approach which includes the analysis and optimization of the exergy demand in the heating and cooling systems as well as in other processes where energy/exergy is used within the building stock" in order to use low valuable energy to meet the energy demands of buildings and reduce energy intensities.

The high energy consumption due to air conditioning equipment in tropical climates, the lack of material and equipment technology availability, building design guides, assessment methodologies and understanding of the life cycle impact and economics constraints in the building sector in countries like Colombia make the necessity to carry out a research oriented in the analysis of building design and systems, for this reasons a thermoecononomic model was developed to assess the construction and operating phases taking into account the north coast weather, conventional and high performance materials and equipment and the cost of the investment, in order to assess the facade impact in the life cycle of buildings.
A parametric study was carried out changing a set of building parameters like aspect ratio, orientation, glass/wall ratio, materials performance. In this way, a vapor compression system was taking as a reference to supply the chilled air and part load performance factor was taken into account to estimate annual energy consumption; to calculate cooling load the CLTD/CLF method was used keeping constant plug load index and occupation factor index. This method will help in the early design stage and policy-makers to assess the sustainability during the building design process.

\section{Model Development}

In order to develop the thermoeconomic model, in each LC steps an inventory and impact assessment was performed in which materials /product, energy and cost flows were gathered from different databases and calculation procedures as is shown in Fig. 2. The detailed calculation procedure for each step is showed next.

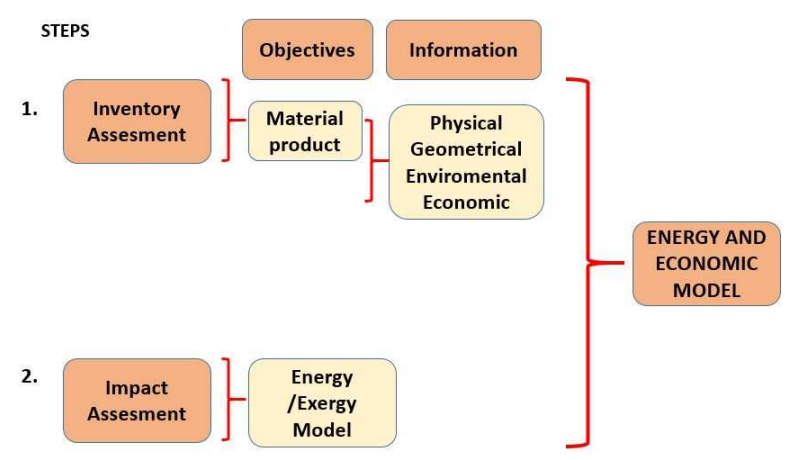

Fig. 2 Schematic view of the thermoeconomic model.

\section{A. Construction phase}

At this stage it is necessary to make an inventory of the materials from which the facade is necessary to provide features such as:

- Physical dimensions: thickness, density,

- Thermal properties: thermal conductivity, specific heat

- Embodied Energy of materials MJ / kg

The result of this stage is to quantify the exergy consumed and losses incurred in the manufacture of materials.

Now, to get the values of embodied energy of the different facades materials, data base of EduPack CES 2010 software, several studies in the field such as:, Weir \& Muneer (1996); Asif, et al (2002); Venkatarama, et al (2003), the studies of the Center of Building Performance Research of the University of Wellington at Victoria and other research sources were took into account.

However, for the calculation of the exergy of the material due to the lack of information and the assumptions used by Cornelissen (1997) based in the method of cumulative exergy consumption (CExC) was used (Szargut, 2005). In this way, the following formula can be written: 


$$
\begin{aligned}
& \text { Ex }_{\text {Material }_{i}}=\left(E . E_{i} \cdot * e_{i} * A_{\text {facade }} \text { component }_{i} * \rho_{i}\right) * \\
& \text { (F.Ex) (1) }
\end{aligned}
$$

The facade components are:

- Walls

- Roof

- Windows

In the following table can be observed the embodied energy per square meter of some of the material and components took into account:

\begin{tabular}{|c|c|c|c|}
\hline Material & $\begin{array}{c}\text { Embodied } \\
\text { Energy } \\
(\mathrm{MJ} / \mathrm{kg})\end{array}$ & $\begin{array}{l}\text { Weight } \\
\text { (kg) }\end{array}$ & $\begin{array}{c}\text { Embodied } \\
\text { energy per } \\
\text { square meter } \\
\left(\mathrm{MJ} / \mathbf{m}^{2}\right)\end{array}$ \\
\hline $\begin{array}{l}\text { Ceramic Tile x } 70 \mathrm{~mm} \\
\text { thickness }(\mathrm{CT} 1)\end{array}$ & 2.5 & 4.5 & 136 \\
\hline $\begin{array}{l}\text { Ceramic Tile x } 90 \mathrm{~mm} \\
\text { thickness }(\mathrm{CT} 2)\end{array}$ & 2.5 & 5.5 & 166 \\
\hline $\begin{array}{l}\text { Concrete Block x 200mm } \\
\text { thickness (CB 1) }\end{array}$ & 0.94 & 19 & 232 \\
\hline AAC Brick & 2.1 & 14.4 & 243 \\
\hline $\begin{array}{c}\text { CT1 + Polystyrene }(25.4 \\
\mathrm{mm})\end{array}$ & - & - & 195 \\
\hline $\begin{array}{c}\text { CT1 + Polyurethane }(25.4 \\
\text { mm })\end{array}$ & - & - & 192 \\
\hline $\begin{array}{c}\text { CT2+Polyurethane } \\
(25.4 \mathrm{~mm})\end{array}$ & - & - & 222 \\
\hline
\end{tabular}

Table 1 Embodied energy of different wall systems

Table 2 Embodied energy of different window systems

\begin{tabular}{|c|c|}
\hline Material & 1120 \\
\hline $\begin{array}{c}\text { Single Panel window, PVC } \\
\text { frame }\end{array}$ & 3905 \\
\hline $\begin{array}{c}\text { Embodied energy per } \\
\text { square meter }\left(\mathbf{M J} / \mathbf{m}^{2}\right)\end{array}$ \\
\hline $\begin{array}{c}\text { Aluminum frame } \\
\text { Single panel window, wood } \\
\text { and Aluminum frame }\end{array}$ & 622 \\
\hline $\begin{array}{c}\text { Double Panel window, PVC } \\
\text { frame }\end{array}$ & 1250 \\
\hline $\begin{array}{c}\text { Double Panel window, } \\
\text { Aluminum frame }\end{array}$ & 4028 \\
\hline $\begin{array}{c}\text { Double panel window, } \\
\text { wood and Aluminum frame }\end{array}$ & 828 \\
\hline
\end{tabular}

\section{B. Operating phase}

To perform an exergy analysis a first law analysis is required first. The building energy consumption is the result of the cooling and ventilation equipment, lighting and appliance operation. So is necessary to get these values.

The cooling load of the building can be divided into:

- Internal: defined by the heat released by people on the basis of work performed and the internal equipment operating schedule including lighting. In this part, load densities by building type were gathered from literature and are showed next.

Table 3 Plug load densities by building type.

\begin{tabular}{|c|c|}
\hline Building type & $\mathbf{W} / \mathbf{m}^{2}\left(\mathbf{W} / \mathbf{f t}^{2}\right)$ \\
\hline Office & $6.9(0.64)$ \\
\hline School & $5.2(0.48)$ \\
\hline
\end{tabular}

\begin{tabular}{|c|c|}
\hline Building type & Persons $/ 100 \mathrm{~m}^{2}\left(\right.$ Persons $\left./ \mathbf{1 0 0 0} \mathrm{ft}^{2}\right)$ \\
\hline Office & $3.1(2.9)$ \\
\hline School & $11.5(10.7)$ \\
\hline
\end{tabular}

Table 4 Occupancy densities by building type.

Table 5 Rates of heat gain from occupants of conditioned spaces (McQuiston, Parker, \& Spliter, 2005)

\begin{tabular}{|c|c|c|c|}
\hline Activity & $\begin{array}{c}\text { Sensible } \\
\text { Heat (W) }\end{array}$ & $\begin{array}{c}\text { Latent } \\
\text { Heat (W) }\end{array}$ & $\begin{array}{c}\text { Total heat } \\
\text { Adjusted (W) }\end{array}$ \\
\hline $\begin{array}{c}\text { Seated, very light } \\
\text { work }\end{array}$ & 72 & 45 & 117 \\
\hline $\begin{array}{c}\text { Moderately active } \\
\text { office work }\end{array}$ & 73 & 59 & 132 \\
\hline Sedentary work & 81 & 81 & 162 \\
\hline
\end{tabular}

Table 6 Artificial light densities by building type

\begin{tabular}{|c|c|}
\hline Building type & $\mathbf{W} / \mathbf{m}^{2}\left(\mathbf{W} / \mathbf{f t}^{2}\right)$ \\
\hline Residential & $5-8$ \\
\hline Office & $16(1.5)$ \\
\hline School & $19.4(1.8)$ \\
\hline
\end{tabular}

-External: The thermal loads were: Heat transmission through walls and roofs; Conductive Heat transmission through windows; Radiation Heat transmission through windows; Ventilation and infiltration loads (sensible and latent). Both cooling loads were calculated using the CLTD/CLF procedure outlined in the ASHRAE Fundamental Handbook (ASHRAE, 1989) applying the latitude and temperature corrections. For this a typical day and design day were calculated from climatic data gathered from data bases.

\section{Cooling equipment energy consumption}

After having quantified the thermal load is necessary to know the energy required to power the air conditioning system. This can be calculated from the system's efficiency or CO. This can be assumed constant or based on outside temperature to take into account the part load performance.

If the COP is constant is set as:

Where

$$
C O P=\frac{\dot{Q}_{T}}{\dot{W}_{D}}(2)
$$

$$
\begin{aligned}
& \dot{Q}_{T}=\text { Cooling load }=\dot{Q}_{\text {internal }}+\dot{Q}_{\text {external }} \text { (3) } \\
& \text { - } \quad \dot{W}=\text { driving power in Watt o } \mathrm{kW} .
\end{aligned}
$$


In a vapor compression heat engine this power is:

- Compressor power

- Evaporator fan power

- Condenser fan power

On the other hand, if COP varies in term of outside temperature, it can be defined as (Kreider, 1994):

Where:

$$
C O P(P L R)=\frac{C_{\text {full }} \cdot P L R}{A+B(P L R)+C(P L R)^{2}}(4)
$$

$$
\text { PRL }=\text { Part Load Ratio }=\frac{\dot{Q}_{\text {cool }}}{\dot{Q}_{\text {full }}}=\frac{\dot{Q}_{T}}{\dot{Q}_{T_{\text {peak load }}}}(5)
$$

A, B and C are part load coefficients obtained from literature (Kreider, 1994).

\section{1) Total energy consumption}

The building energy consumption is the sum of:

$$
\dot{E}_{\text {Total }}=\dot{E}_{\text {Elec internal }}+\dot{W}_{D}(6)
$$

$\dot{W}_{D}=$ required electricity to operate the cooling equipment.

$\dot{E}_{\text {Elec internal }}=$ electricity to operate the internal equipment. i.e. illumination, appliance or plug equipment.

\section{Exergy Analysis}

The exergy analysis starts in the envelope and goes through the cooling equipment until the energy supply source (primary or final consumer energy, i.e. electricity). This method is similar to carrying out a process analysis beginning at the final link and running through the processes (Szargut, 2005). The method followed is the proposed of Schmitd and co-workers in the IEA ESCB Annex 37 that could be established as a process analysis. In Fig. 3 is shown the methodology for carrying out an exergy analysis in a Building using vapor compression cooling equipment to achieve comfort conditions.

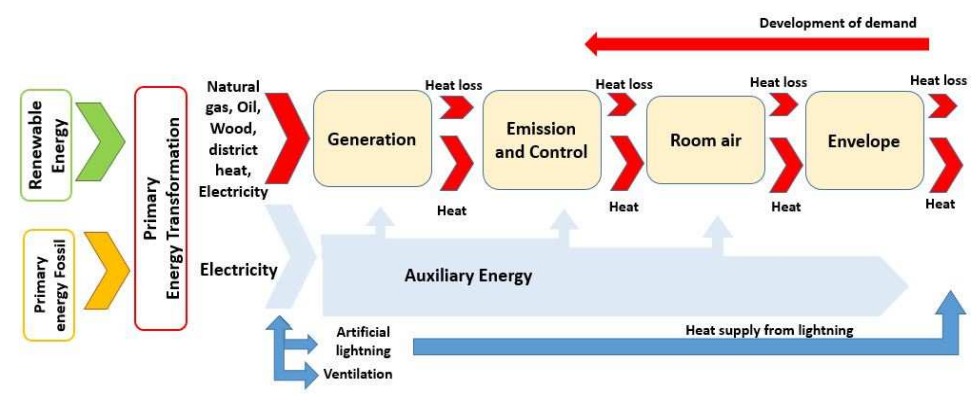

Fig. 3. Schematic diagram of an energy (exergy) analysis of a building and VC cooling equipment. Source: IEA ECBCS Annex 37)

\section{2) Envelope Heat Transmission load}

This loss is due irreversible heat transfer through building envelope. This exergy transfer is determined by the cooling load and the Carnot factor:

$$
\dot{E} x_{Q}=\dot{Q}_{T} *\left(\frac{T_{i n t}-T_{\text {ext }}}{T_{\text {int }}}\right)(7)
$$

The Carnot factor takes into account the interior and exterior temperature.

\section{3) Exergy of Comfort Air (Room air)}

This could be expressed in function of the air temperature and humidity supplied to the room or building area. That relationship was developed by Bejan, 1988 (Alpuche, Heard, Best, \& Rojas, 2005):

$$
\begin{gathered}
e_{\text {wet air }}=\left(c_{p, a}+\omega c_{p, v}\right) T_{0}\left(\frac{T}{T_{0}}-1-\ln \frac{T}{T_{0}}\right)+ \\
(1+\bar{\omega}) R_{a} T_{0} \ln \frac{P}{P_{0}}+R_{a} T_{0}\left((1-\bar{\omega}) \ln \frac{1+\overline{\omega_{0}}}{1+\bar{\omega}}+\bar{\omega} \ln \frac{\bar{\omega}}{\overline{\omega_{0}}}\right)
\end{gathered}
$$

Now, the exergy flow of the supplied air would be obtained from:

$$
\dot{E} x_{\text {humid air }}=\dot{m}_{\text {air }} * e_{\text {humid air }}(9)
$$

The air flow is calculated from the follow relationship derived from a energy balance in the heat exchanger coil:

$$
\dot{Q}=\dot{m}_{a i r} * c_{p_{a i r}} *\left(T_{a, \text { ent }}-T_{a, \text { leav }}\right)(10)
$$

The temperature difference is assumed in the range of $5^{\circ} \mathrm{C}-10^{\circ} \mathrm{C}$, values typical from this kind of system. Where $\dot{Q}$ is total heat flow load due to external and internal heat gains. This concept is the same defined by Shakuya in 1996 named cool exergy, because the room air temperature is above the outdoor air (IEA, Annex 37, Guidebook)

\section{4) Cooler exergy emission}

The cooler exergy load results due to the heat transfer between the evaporator and the room air. This load could be obtained from the equation

$$
\dot{E} x_{\text {cooler }}=\dot{Q}_{T}\left(1-\frac{\mathrm{T}_{\text {ext }}}{\mathrm{T}_{\text {evap }}}\right)(11)
$$

$\mathrm{T}_{\text {evap }}$ is obtained from the logarithmic mean temperature of a heat exchanger carrying the cooling load. In this step based in the cooling load and refrigerant properties, this value could be estimated.

\section{Exergy Efficiency}

Finally, as HVAC systems could be considered a Carnot machines, its rational exergy efficiency can be obtained with the following formula (Szargut, 2005)

$$
\eta_{\text {ex }}=\frac{Q_{T}}{W_{D}}\left(\frac{T_{\text {in }}-T_{0}}{T_{\text {in }}}\right)(12)
$$

Where:

$$
C O P=\frac{Q_{u}}{W_{D}}(13)
$$

And

$$
F_{q, \text { Carnot }}=\left(1-\frac{T_{0}}{T_{\text {in }}}\right)(14)
$$


So the exergy efficiency in part load case could be rewritten like:

$$
\begin{gathered}
\eta_{\text {ex }}=\operatorname{COP}(P L R) \cdot\left(\frac{T_{\text {in }}-T_{0}}{T_{\text {in }}}\right)(15) \\
\eta_{\text {ex }}=\frac{\operatorname{COP}_{\text {full }} \cdot P L R}{A+B(P L R)+C(P L R)^{2}} \cdot\left(\frac{T_{\text {in }}-T_{0}}{T_{\text {in }}}\right)
\end{gathered}
$$

\section{Remembering that; PRL = Part Load Ratio}

\section{Thermoeconomic accounting}

\section{A. Life Cycle Costing}

In a LCC the objective is to quantify the cost through:

$$
L C C=C_{\text {oper }}+C_{\text {Inv }}+C_{M n t c}(17)
$$

Where:

- $C_{\text {Inv }}=$ Investment Cost

- $C_{\text {oper }}=$ Operation Cost

- $C_{\text {Mtto }}=$ Maintenance Cost

$L C C$ is the good production cost and is equal to $C_{p}$ in $\$$ /year. Now, combining exergy and economic accounting the LCEC would be:

$$
\begin{gathered}
C_{p}=c_{\text {oper }} \cdot \dot{E} x_{\text {oper }}+C_{\text {Inv }}+C_{M}(18) \\
c_{p} \cdot \dot{E} x_{p}=c_{\text {oper }} \cdot \dot{E x_{o p e r}}+C_{\text {Inv }}+C_{M}(19)
\end{gathered}
$$

Where:

- $E x_{p}$ could be total heat flow load or the envelope heat exergy transmission load in $\mathrm{MJ} / \mathrm{m}^{2}$-year

- $\quad c_{\text {oper }}$ is the fuel cost (electricity) in $\$ / \mathrm{kW}-\mathrm{h}$ $(\$ / \mathrm{MJ})$

- $\quad E x_{\text {oper }}$ is the electrical exergy flow per year to operate the building systems in $\mathrm{MJ} / \mathrm{m}^{2}$-year like: HVAC and illumination and plug loads.

- $\quad C_{i n v}$ is the cost of construction and building service equipment cost per year, taking into account the interest rates and payment rates in a time horizon

$C_{i n v}$ could be rewritten as:

$$
C_{i n v}=c_{B C P} \cdot \dot{E} x_{B C M}+C_{i n v_{-} o}
$$

Where:

- $\quad \dot{E} x_{B C M}=$ exergy consumption of Building Construction materials (BCM) in $\mathrm{MJ} / \mathrm{m}^{2}$-year. This can be derived from the concept of CExC show in Szargut (2005), so $\dot{E} x_{B C P}=C E \dot{x} C_{B C P}$. This term is annualized taking into account the life time $(\Delta t)$ of the material and the cexc in $\mathrm{MJ} / \mathrm{kg}$.

$$
\dot{E} x_{B C P_{i}}=\frac{\frac{\mathrm{kg}}{\mathrm{m}^{2} \text { wall }_{i}} \cdot \mathrm{m}^{2} \text { Total wall }_{i} \cdot \text { Cexc }_{i}}{\Delta t_{\mathrm{i}} \cdot \mathrm{m}^{2} \text { construc }}(20)
$$

$$
\dot{E} x_{B C P_{i}}=\frac{k g_{\text {Total wall }_{i} \cdot \operatorname{cexc}_{i}}}{\Delta t \cdot \mathrm{m}^{2} \text { construc }}(21)
$$

- $\quad c_{B C P}=$ cost of building construction materials in $\$ / \mathrm{MJ}$.

$$
c_{B C P_{i}}=\frac{\operatorname{Cost}_{i}}{\operatorname{cexc}_{i}}=\frac{\$ / k g}{M J / k g}(22)
$$

- $C_{\text {inv_o }}=$ annualized cost of other investment building system equipments in (\$/year)

If the equation (19) is divided by $\dot{E} x_{p}$, and considering that maintenance cost $\left(C_{M}\right)$ are negligible the LCEC is:

$$
c_{p}=\frac{c_{\text {oper }} \cdot \dot{E} x_{\text {oper }}}{\dot{E} x_{p}}+\frac{C_{I n v}}{\dot{E x}}(23)
$$

$c_{p}=$ total exergy construction cost in $\$ / \mathrm{MJ}$;

$c_{\text {oper }}=$ price of electricity in $(\$ / \mathrm{kW}-\mathrm{h} ; \$ / \mathrm{MJ})$;

Rewriting the latter equation results in:

$$
\begin{aligned}
& c_{p}\left(\frac{\$}{M J}\right)=c_{\text {oper }} \cdot\left(\frac{\dot{E} x_{i l l u m}}{E x_{p}}+\frac{E x_{\text {cool }}}{E x_{p}}+\frac{\dot{E x_{p l u g}}}{\dot{E} x_{p}}\right)+ \\
& \sum_{i=1}^{n, m} C_{B C M_{i}} \cdot \frac{\dot{E x_{B C M_{i}}}}{\dot{E} x_{p}}+\frac{C_{I n v}}{E x_{p}}(24) \\
& c_{p}\left(\frac{\$}{M J \cdot y}\right)=c_{\text {oper }} \cdot\left(\frac{1}{\eta_{\text {ex illum }}}+\frac{1}{\eta_{\text {ex } \text { Cool }}}+\frac{1}{\eta_{\text {explug }}}\right)+ \\
& \sum_{i=1}^{n, m} C_{B C M_{i}} \cdot \frac{1}{E x_{p} / \dot{E x}_{B C M_{i}}}+\frac{C_{I n v}}{E x_{p}}(25)
\end{aligned}
$$

$\frac{E x_{p}}{E x_{B C M}}$ is defined as the exergy efficiency of building material investments, in which the exergy required to construct the facade is related to the cooling exergy load. This term shows the relative impact of material selection in the cooling load demands of the building. In this way is possible to calculate the cost of an option that consumes certain amount of exergy in terms of exergy efficiency of different buildings energy services like illumination, cooling equipment and material investments. In the other hand, in the building context the cost of an option must have units of $\$ / \mathrm{m}^{2}$-year so the thermoeconomic accounting has the form of:

$$
C_{p}=c_{\text {oper }} \cdot \dot{E} x_{\text {oper }}+c_{B C P} \cdot \dot{E} x_{B C M}+C_{i n v_{-} o}
$$

\section{Avoided exergy cost due to recyclability (or end of life exergy content)}

Due to the different end use potential of some materials like: combustion, reprocessing, recycle or reuse is possible to calculate the avoided exergy cost associated with the recycling activities. With this in mind, is possible compare the impact of the required energy for production/processing a recycled material. The next figure shows the embodied energy of different materials options in a window frame.

Table 7 Virgin and recycle embodied energy of metallic materials. 


\begin{tabular}{|c|c|}
\hline & $(\mathbf{M J} / \mathbf{k g})$ \\
\hline Aluminum, virgin extruded, anodized & 225 \\
\hline Aluminum, recycled extruded, anodized & 43 \\
\hline Steel, virgin, galvanized & 35 \\
\hline Steel, recycled, galvanized & 10 \\
\hline
\end{tabular}

The thermoeconomic equation can be rewritten as:

$C_{p}=\left(\sum_{i=1}^{n, m} c_{\text {oper }_{\text {fuel }_{i}}} \cdot\left(C E x C_{\text {bm }}-C E C_{\text {recycled }}\right)_{\text {oper }_{B C P_{i}}}\right)+$

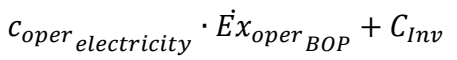

Where:

$\mathrm{n}=$ fuel type; $\mathrm{m}=$ building material type

\section{Conclusions}

In tropical countries the most important factor that affect the exergy efficiency and the cost of operation is associated to design stage.

1) Due to climate condition model must take into account robust parameters that allow to estimate global efficiency under different operation conditions such as incresing population, area/habitant, and building energy intensity which implies

2) During construction phase there are many restrictions due to lack of information for the calculation of exergy of materials. Also, used values correspond to measurements made for other countries where climate conditions are not such as similar. However, as a first exercise allow to estimate global efficiency.

3) During Operation phase, an approach was made using a first law analysis on cooling load process and cooling equipment energy consumption, many parameters were assumed as constant which is not true in these hot and humid places where nominal conditions are different than the ones asked by manufacturer. For further calculations, corrections should be made on this calculations by adding new inputs related to efficiency decreasing .

\section{References}

[1] Alpuche, M. G., Heard, C., Best, R., \& Rojas, J. (2005). Exergy analysis of air cooling systems in hot humid climates. Applied Thermal Engineering 25, 507-512.

[2] Al-Rabghi, O., \& Hittle, D. (2001). Energy Simulation in Buildings: overview and BLAST example. . Energy Conversion and Managment 42. Elsevier, 1623-1635.

[3] ASHRAE. (1989). ASHRAE Fundamental Handbook. In CLTD/CLF Method.

[4] Climate Protection Partnership Division . (2008, Octubre). Reducing Urban Heat Island: Compendium of Strategies. Urban Heat Island Basics. Retrieved Junio 2010, from sitio web U.S. EPA:

http://www.epa.gov/heatisld/resources/pdf/BasicsCompendium.p df

[5] Cole, R. J., \& Kernan, P. C. (1996). Life-Cycle Energy Use in Office Buildings. Building and Environment, vol. 31, $N^{\circ} 4$, 307317.
[6] Cornelissen, R. (1997). Thermodynamics and sustainable development. $\quad$ Retrieved 2010, from http://doc.utwente.n1/32030/1/t0000003.pdf

[7] Gauzing-Muller, D. (2001). Arquitectura ecológica: 29 ejemplos europeos. París: Grupo Moniteur.

[8] Gong, M., \& Wall, G. (1997). On exergetics, economics and optimization of technical processes to meet environmental conditions. TAIES'97. International Conference on Thermodynamic Analysis and Improvement of Energy Systems. Beijing, China.

[9] Haapio, A., \& Viitaniemi, P. (2008). A critical review of building environmental assessment tools. Environmental Impact Assessment Review 28 , 469-482.

[10] Kibert, C. (2008). Sustainable Construction: Green Building Design and Delivery (2nd. ed.). New Jersey: Jhon Wiley \& Sons.

[11] Kofoworola, O. F., \& Gheewala, S. H. (2009). Life cycle energy assessment of a typical office building in Thailand. Energy and Buildings 41 , 1076-1083.

[12] McQuiston, F. C., Parker, J. D., \& Spliter, J. D. (2005). Heat, ventilating, and aire aconditioning: Analysis and Design. John Wiley \& Sons.

[13] O'Connor, J., Lee, E., Rubinstein, F., \& Selkowitz, S. (1997). Building Technologies. Lawrence Berkeley National Laboratory. Retrieved from http://btech.lbl.gov/pub/designguide/dlg.pdf

[14] Passive House Institute. (n.d.). What is passive house? Retrieved Enero 2011, from http://www.passiv.de/07_eng/index_e.html

[15] Saidur, R. (2009). Energy consumption, energy savings and emission analysis in Malaysian Office Buildings. Energy Policy $37,4104-4113$.

[16] Santamouris, M., Papanikolau, N., Livada, I., Koronakis, I., \& Georgakis, C. (2001). On the impact of urban climate on the energy consumption of buildings. Solar Energy. Vol. 70, $N^{\circ} 3$, , 201-216.

[17] Sartori, I., \& Hestnes, A. (2007). Energy use in the life cycle of conventional and low-energy buildings: A review article. Energy and Buildings 39, 249-257.

[18] Szargut, J. (2005). Exergy method: technical and ecological applications. Great Britain: WIT Press.

[19] Torcellini, P., Pless, S., Deru, M., \& Crawly, D. (2006, Junio). Zero Energy Building: A critical look at the definition. National Renewable Energy laboratory. Retrieved Enero 28, 2011, from http://www.nrel.gov/docs/fy06osti/39833.pdf.

[20] Yildiz, A., \& Güngör, A. (2009). Energy and exergy analysis of space heating of buildings. Applied Energy 86, 1939-1948.

[21] Center for Building Performance Research. Victoria University of Wellintong. Embodied Energy. Recuperado el: 4 de Julio de 2010, de http://www.victoria.ac.nz/cbpr/projects/embodiedenergy.aspx

[22] Balsano J, Parra R, Jiménez P. (2005). Estimate of energy consumption and $\mathrm{CO} 2$ emission associated with the production, use and final disposal of PVC, aluminium and wooden Windows. Universitat Politecnica de Catalunya. Environmental Modelling Laboratory. Barcelona, Abril 2005. Recuperado el: 12 de Agosto de 2010, de: http://www.pvcinfo.be/bestanden/Baldasano\%20study_windows. pdf

[23] Asif M, Davinson A, Munner T. (2002) Life cycle of window materials - a comparative assessment. Napier University, School of Engineering. UK. Recuperado el: 12 de Agosto de 2010, de:: www.cibse.org/pdfs/Masif.pdf. Consultado: Agosto 2010.

[24] De Meester B., Dewulf J., Verbeke S., Janssens A., Van Lagenhove H. (2009). Exergetic life-cycle assessment (ELCA) for resource consumption evaluation in the built environment. Building and Environment 44 (2009) 11-17.

[25] IEA ECBCS Annex 37. Low exergy systems for heating and cooling of Buildings. Guidebook. http://www.lowex.net/guidebook/index.htm

[26] IEA ECBCS Annex 49. Low Exergy Systems for HighPerformance Buildings and Communities http://www.annex49.com/background.html 
[27] ISO 14040: Environmental Management- Life Cycle Assessment-Principles and Framework.

[28] Kreider J F, Rabl A. (2007). Heating and cooling of buildings: design for efficiency. Taylor \& Francis, 2007

[29] Salazar J. Life Cycle assessment case study of North American residential Windows. Thesis for the degree of master of Science. University of British Columbia. December 2007. Recuperado el: 12 de Agosto de 2010, de: https://circle.ubc.ca/bitstream/handle/2429/919/ubc_2008_spring _salazar_james.pdf?sequence $=1$

[30] Schmidt D., Ala-Juusela M., Low exergy systems for heating and cooling of buildings. Plea2004 - The 21st Conference on Passive and Low Energy Architecture. Eindhoven, The Netherlands, 19 - 22. September 2004. Recuperado el: Julio de 2010 http://www.ibp.fraunhofer.de/Images/KB\%20eng\%205_tcm4530971.pdf

[31] Venkatarama B, Jagadish K.(2003). Embodied energy for common and alternative building materials and technologies. Energy and Buildings 35 (2003) 129-137.

[32] Wier G, Muneer T. (1996). Energy and environmental impact analysis of double-glazed Windows. Energy Conversion and Managment 39 No. 3/4 243-256. 